\title{
A case report on penicillin/co-trimoxazole induced Jarisch Herxheimer reaction in secondary syphilis with human immunodeficiency virus
}

\author{
Suruthi Lakshmi Narayanan, Afsal Ahammed, Arun Chander Yadav Krishnamurthy*
}

Department of Clinical Pharmacology, Apollo Hospital, Chennai, Tamil Nadu, India

Received: 30 September 2021

Accepted: 22 October 2021

*Correspondence:

Dr. Krishnamurthy ACY,

Email: drarunchander_k@apollohospitals.com

Copyright: (c) the author(s), publisher and licensee Medip Academy. This is an open-access article distributed under the terms of the Creative Commons Attribution Non-Commercial License, which permits unrestricted non-commercial use, distribution, and reproduction in any medium, provided the original work is properly cited.

\begin{abstract}
The Jarisch-Herxheimer reaction (JHR) typically occurs after the initiation of antibiotic treatment in syphilis. Although JHR was identified and looked at over many years, the prevention and management of JHR remain unclear. Previous reports have described the occurrence of JHR due to antibiotic treatment in syphilis, we presented a case of a young man with recurrence of JHR in syphilis, first due to penicillin which later was worsened due to co-trimoxazole.
\end{abstract}

Keywords: Antibiotic treatment, Jarisch-Herxheimer, Syphilis, Penicillin, Co-trimoxazole

\section{INTRODUCTION}

The JHR has been previously observed in patients with syphilis who undergo anti-microbial treatment. It has been reported to develop in $75-80 \%$ of syphilis patients who are treated. ${ }^{1}$

The JHR usually occurs within a few hours of commencement of anti-microbial treatment in patients with primary or secondary syphilis. ${ }^{2}$ The patients with JHR generally present with fever, headache, chills, hypotension, sweating, rigors and myalgia, along with exacerbation of existing skin lesions. ${ }^{1,3}$

We herein reported a case of a 27 years old man with HIV and secondary syphilis whose condition was worsened by JHR due to the treatment with penicillin and co-trimoxazole. He presented with fever, erythematous skin and genital lesions following the administration of penicillin, which later was worsened due to the administration of co-trimoxazole.

\section{CASE REPORT}

A 27 years old male diagnosed with PLHIV-CDC3 WHO stage IV and secondary syphilis, on anti-retroviral therapy (ART) started last month, presented to our emergency department with complaints of excessive erythematous skin lesion associated with itching, complaints of dry cough and mild chest pain. He was found to have normal body temperature, a pulse rate of 82 beats per minute, blood pressure of $130 / 80 \mathrm{mmHg}$ and a respiratory rate of 20 breaths per minute. He was treated with $1 \mathrm{~g}$ paracetamol intravenously and anti-histamine (fexofenadine) orally. His absolute CD4 count values were abnormal, tested during admission (Table 1). He was positive to SARS-CoV-2 antibody.

He was initially evaluated in the outpatient department (OPD) for complaints of skin lesions in the body, palms, and soles for the last few weeks. He was also found to have genital lesions. He had no previously known drug allergies and he was treated symptomatically with steroids and local application cream (details not available) and got better initially. He tested positive for VDRL (syphilis) and HIV-I antibody on 29 July 2021. ART with 
dolutegravir+lamivudine+tenofovir (TLD) along with penicillin was started on 31 July 2021 and he received three doses of penicillin on 31 July 2021, 7 August 2021 and 14 August 2021

He was eventually admitted to our hospital for further evaluation and management on 29 August 2021. Upon admission to the ward, he was treated with IV paracetamol, tablet co-trimoxazole (sulfamethoxazole 800 $\mathrm{mg}$ and trimethoprim $160 \mathrm{mg}$ ) and a moisturizing lotion (Venusia Max). His symptoms worsened with itching, persistent high-grade fever, rigors, worsening of periorbital puffiness, skin lesions, decreased appetite and dark colored urine after two doses of co-trimoxazole. TLD-ART and co-trimoxazole were stopped. A dermatologist's opinion was obtained, and he prescribed prednisolone orally. Blood workup was done prior to and after the reaction (Table 2). His $\mathrm{Hb}, \mathrm{PCV}$ levels were low, and WBC, ESR and RDW values were higher after the response. Liver function test (LFT) revealed increased levels of total bilirubin, conjugated bilirubin, total protein, ALT, AST and decreased globulin levels (Table 3). He was shifted to HDU on that evening and he was treated with meropenem and tigecycline intravenously. He had hyponatremia, IV fluids were changed from RL to NS and he increased oral salt intake.

Table 1: Patient's Absolute CD4 Count.

\begin{tabular}{|llll|}
\hline S. no. & Absolute CD4 count & Patient's value & Reference interval \\
\hline 1. & CD3+(T cell) & 84 & $67-81 \%$ of positive cells/ $\mu 1$ \\
\hline 2. & CD3+(T cell) & 1075 & $877-1815$ \\
\hline 3. & CD4+(helper T cells $)$ & 28 & $30-77 \%$ of positive cells $/ \mu 1$ \\
\hline 4. & CD4+(helper T cells $)$ & 292 & $328-2130$ \\
\hline 5. & CD8+(cytotoxic T cells $)$ & 69 & $19-33 \%$ of positive cells $/ \mu 1$ \\
\hline 6. & CD8+(cytotoxic T cells $)$ & 740 & $200-616$ \\
\hline 7. & CD4:CD8 ratio & 0.39 & $>1.0$ \\
\hline
\end{tabular}

CD - Cluster of differentiation.

Table 2: Patient's Haematological parameters before and after JHR.

\begin{tabular}{|c|c|c|c|c|}
\hline S. no. & Haematological parameters & $\begin{array}{l}\text { Patient's value before } \\
\text { JHR }\end{array}$ & $\begin{array}{l}\text { Patient's value after } \\
\text { JHR }\end{array}$ & Reference interval \\
\hline 1. & HB (g/dl) & 11.5 & 9.2 & $13-18$ \\
\hline 2. & $\mathrm{PCV}(\%)$ & 37 & 28 & $40-54$ \\
\hline 3. & $\mathrm{WBC}\left(\times 10^{3} / \mathrm{mm}^{3}\right)$ & 9.51 & 14.05 & $4-11$ \\
\hline 4. & $\operatorname{PLT}\left(\times 10^{3} / \mathrm{mm}^{3}\right)$ & 159 & 150 & $150-450$ \\
\hline 5. & ESR $(\mathrm{mm} / \mathrm{hr})$ & 8 & 16 & $0-15$ \\
\hline 6. & RDW (\%) & 19 & 18.6 & $11.6-14.5$ \\
\hline 7. & Neutrophils (\%) & 76 & 70 & $40-80$ \\
\hline 8. & Lymphocytes (\%) & 11 & 21 & $20-40$ \\
\hline 9. & Monocytes (\%) & 5 & 9 & $2-10$ \\
\hline 10. & Eosinophils (\%) & 8 & - & $1-6$ \\
\hline
\end{tabular}

HB - Hemoglobin, PCV - Packed Cell Volume, WBC - White Blood Cells, PLT - Platelet, ESR - Erythrocyte sedimentation rate, RDW Red Cell Distribution Width.

Table 3: Patient's parameters tested during the reaction.

\begin{tabular}{|llll|}
\hline S. no. & Parameters tested during the reaction & Patient's value & Reference interval \\
\hline 1. & Sodium $(\mathrm{m} \mathrm{Eq} / \mathrm{l})$ & 127 & $136-145$ \\
\hline 2. & Potassium $(\mathrm{m} \mathrm{Eq} / \mathrm{l})$ & 3.4 & $3.5-5$ \\
\hline 3. & Total bilirubin $(\mathrm{mg} / \mathrm{dl})$ & 1.8 & $0.5-1$ \\
\hline 4. & Indirect bilirubin $(\mathrm{mg} / \mathrm{dl})$ & 1.0 & $0.3-0.5$ \\
\hline 5. & Direct bilirubin $(\mathrm{mg} / \mathrm{dl})$ & 0.8 & $0.2-0.6$ \\
\hline 6. & Total protein $(\mathrm{g} / \mathrm{dl})$ & 5.5 & $6-8$ \\
\hline 7. & Serum albumin $(\mathrm{g} / \mathrm{dl})$ & 3.7 & $3.5-5$ \\
\hline 8. & Globulin $(\mathrm{g} / \mathrm{dl})$ & 1.8 & $2-4$ \\
\hline 9. & AST $(\mathrm{IU} / \mathrm{l})$ & 95 & $<35$ \\
\hline 10. & ALT $(\mathrm{IU} / \mathrm{l})$ & 227 & $5-35$ \\
\hline 11. & GGTP $(\mathrm{IU} / \mathrm{l})$ & 36 & $10-50$ \\
\hline 12. & Alkaline phosphatase $(\mathrm{U} / \mathrm{l})$ & 86 & $<128$ \\
\hline
\end{tabular}

AST - Aspartate Aminotransferase, ALT- Alanine Aminotransferase, GGTP - Gamma-Glutamyl Transpeptidase 
The next day, the fever subsided, the facial swelling decreased and all antibiotics were stopped. The dermatologist prescribed dexamethasone intravenously and cyclosporine $100 \mathrm{mg}$ orally. Echocardiogram was done and it revealed mild mitral regurgitation (MR), tricuspid regurgitation (TR) and pulmonary arterial hypertension (PAH) and his left ventricular ejection fraction (LVEF) were found to be $60 \%$. USG abdomen revealed grade-I fatty liver. He had a purulent discharge from his ears, for which ENT opinion was obtained. He was diagnosed with grade-2 follicular tonsillitis.

In the following days, his itching and facial swelling gradually decreased. Intravenous dexamethasone was stopped. He was discharged with potassium chloride suspension, tablet cyclosporine and sitz bath for his anal fissures, which was diagnosed during his discharge. An outpatient follow up was arranged in three days with the dermatologist to ensure further progress.

\section{DISCUSSION}

Syphilis is an infection caused by the bacterium, Treponema pallidum, a spirochete transmitted either sexually or by vertical transmission. Syphilis has been a public health issue/complication. Syphilis was classified into various stages based on the time since infection and symptoms. ${ }^{4}$ People infected with primary syphilis present with a painless chancre or ulcer at the site of infection, but they can also present with several painful lesions. ${ }^{5}$ Secondary syphilis patients were current with a wide variety of systemic symptoms involving headache, fever, rash, lymphadenopathy and pharyngitis. ${ }^{4}$ Patients with tertiary syphilis might present with gummatous lesions, cardiac problems and general paresis. ${ }^{5}$ To limit the clinical effects of the disease, it was essential to prompt appropriate diagnosis and treatment. The data for proper treatment for HIV-infected patients with syphilis was constrained; however, the available evidence showed penicillin as a first-line antibiotic. ${ }^{4}$ It was the preferred drug of choice for treating syphilis patients in all stages and has been used for more than fifty years. ${ }^{4,5}$ Penicillin G was the only anti-microbial therapy of choice for syphilis in pregnancy. ${ }^{5}$

The severity of the JHR was associated with the stages of syphilis. It was severe and fatal in the primary and secondary stages of syphilis when compared to the late tertiary stage. The mechanisms of eventuation of the JHR were not thoroughly understood. However, there were some etiological theories associated with the JHR. The release of endotoxins or lipopolysaccharide in blood by $T$. pallidum was connected with JHR. The other approach of the JHR included the transient increase in the levels of cytokines as a result of antibiotic treatment. The tumor necrosis factor (TNF), the interleukin-8 (IL-8) and the interleukin-6 (IL-6) were related to the JHR, but each of these culminates at different periods throughout the reaction. ${ }^{1}$
The selection of the antibiotic in the treatment of these infections had been associated with JHR. ${ }^{1}$ A prospective observational study about azithromycin versus benzathine penicillin G therapy in HIV positive patients with early syphilis in 2014 by Tsai et al showed that the overall incidence of the JHR was significantly lesser in patients who received azithromycin than those who received benzathine penicillin G. Azithromycin group had $80 \%$ less incidence of JHR compared to the penicillin G group. ${ }^{6}$

The case that we were reporting here had a reaction to penicillin administration with worsening of syphilis erythematous symptoms in an outside OPD and also had a response to co-trimoxazole administration with highgrade fever, worsening of syphilis symptoms (severe itching, worsening of erythematous lesions and increased periorbital facial edema) and rigors in our hospital. The etiology of the initial reaction with penicillin was unclear as it was not directly observed. The history was collected from the patient and further management was carried out in the in-patient setting. The reaction with co-trimoxazole administration happened within a day and a half and the patient was treated with dexamethasone, paracetamol and cyclosporine.

A case report by Mckenzie et al described JHR after cephalosporin administration in syphilis. The patient had a profound reaction to fluid-refractory hypotension and his condition eventually improved after the administration of vasopressor for his hypotension. He also tolerated the further administration of ceftriaxone. ${ }^{7}$ The other case about JHR in secondary syphilis with eosinophilia by Elias et al reported facial erythema and edema after penicillin administration which was treated with prednisone. $^{8}$

In our case, co-trimoxazole administration was stopped and we did not re-challenge co-trimoxazole as the antibiotics were changed to meropenem and tigecycline. However, the fever and rigors subsided within few hours and the itching and facial edema decreased and his lesions started to heal. His condition during discharge was uneventful. While specific clinical criteria meet the typical presentation of JHR, the sequence of events and involvement of different medications make it difficult to point to the JHR with certainty.

\section{CONCLUSION}

The Jarisch-Herxheimer is one of the rare presentations, and it is significant to identify and differentiate it from sepsis and other allergic phenomenon. As the management of the JHR has always been supportive, it is quintessential to report any events closely related to JHR. It is of utmost importance to educate the clinicians about JHR and it would be useful in initiating the anti-microbial therapy to their patients for the management of syphilis. In addition, there should be a clear understanding of JHR 
among clinicians to ensure medication safety in their adieu of patient care.

\section{ACKNOWLEDGEMENTS}

We extend our sincere thanks to Apollo Hospitals, Chennai, India for providing us with clinical data throughout the study period.

Funding: No funding sources

Conflict of interest: None declared

Ethical approval: Not required

\section{REFERENCES}

1. Pound MW, May DB. Proposed mechanisms and preventative options of Jarisch-Herxheimer reactions. J Clin Pharm Ther. 2005;30(3):291-5.

2. Butler $T$. The Jarisch-Herxheimer reaction after antibiotic treatment of spirochetal infections: a review of recent cases and our understanding of pathogenesis. Am J Trop Med Hyg. 2017;96(1):46-52.

3. Belum GR, Belum VR, Arudra SKC, Reddy BS. The Jarisch-Herxheimer reaction: revisited. Travel Med Infect Dis. 2013;11(4):231-7.
4. Clement ME, Okeke NL, Hicks CB. Treatment of syphilis: a systematic review. JAMA. 2014;312(18):1905-17.

5. Workowski KA, Bachmann LH, Chan PA, Johnston CM, Muzny CA, Park I, et al. Sexually transmitted infections treatment guidelines, 2021. MMWR Recomm Rep. 2021;70(4):1-187.

6. Tsai MS, Yang CJ, Lee NY, Hsieh SM, Lin YH, Sun HY, et al. Jarisch-Herxheimer reaction among HIVpositive patients with early syphilis: azithromycin versus benzathine penicillin G therapy. J Int AIDS Soc. 2014; 17:18993.

7. McKenzie C, Olges J. Jarisch-Herxheimer reaction after cephalosporin administration in syphilis. Cureus. 2021;13(1):12750.

8. Elias A, Wark K, Slape D, Cook D, Lee K, Mckew G. Secondary syphilis with eosinophilia complicated by severe Jarisch-Herxheimer reaction. Case Rep Infect Dis. 2020;2020:2150314.

Cite this article as: Narayanan SL, Ahammed A, Krishnamurthy ACY. A case report on penicillin/cotrimoxazole induced Jarisch Herxheimer reaction in secondary syphilis with human immunodeficiency virus. Int J Basic Clin Pharmacol 2021;10:1427-30. 